\title{
Evaluation of Efficient Consumer Response (ECR) Processes in Retail Companies in the Baltic States
}

\author{
Iveta Liniņa, Rosita Zvirgzdiņa \\ Turiba University
}

\begin{abstract}
The primary goal of retail operations similar to any other business is to make a profit by satisfying consumer needs. To achieve the goal and ensure competitiveness retail enterprises need to carry out their operations as efficiently as possible by applying the latest, most modern work organisation methods. Work efficiency can be achieved by reducing supply chain costs which in turn can be achieved through successful cooperation among all the parties involved. Efficient Consumer Response (ECR) is not just a new approach to process organisation in retail trade but affects all business processes as a whole taking them to a totally new and much higher level, thereby ensuring an increase in customer satisfaction and loyalty levels. The aim of the present research is to review the latest scientific literature on ECR, understand its working principles and carry out a survey of experts in order to ascertain the level of application of ECR in retail enterprises in the Baltic States and put forward recommendations for the enhancement of application of ECR.
\end{abstract}

Keywords: customer satisfaction, loyalty, relationship management, retail trade.

\section{INTRODUCTION}

Despite the overall growth of the retail trade sector, internal competition within the respective sectors is increasing. Therefore it is very important to find opportunities on how to successfully survive and develop in circumstances of intense competition. The consumer is the one who makes the choice and the satisfaction of the consumer needs is the primary goal of retail trade. The consumer's choice is based on the good (assortment and quality), price and place. The consumer would also like the service to meet their expectations and to receive the necessary information. In the modern information era it is easy for consumers to gain information about the best offer on the market and retail enterprises have to come up with solutions to be leaders in the fight to attract consumers and maintain long term relationships with them. According to existing research [1] the cost of attracting new customers is $5-10$ times more expensive than selling to your existing ones and existing customers spend $67 \%$ more money than new customers. Therefore it is essential that retail enterprises work out a system that would create desire in existing customers to carry out repeat purchases and continue their relationship. One of the systems offered for ensuring efficient operations in retail trade is ECR (Efficient Consumer Response). An American marketing management firm has researched that the benefit of introduction of ECR would be a reduction of retail prices by $10.8 \%$ [13]. It is expected that manufacturers receive $54 \%$ of the savings and distributers and retailers could receive the remaining $46 \%$ [8].

The research reviewed the use of most popular efficient consumer response (ECR) principles in retail trade. ECR system elements are never a finished process but an enhancement tool for enterprises.

The aim of the research is to assess the level of use of ECR systems and development perspectives in retail enterprises as an effective tool for increasing its competitiveness.

The following tasks were set for achieving the aim:

1. Study the theoretical base of ECR.

2. Characterise the retail trade sector in the Baltic States and the prerequisites for implementing ECR in retail trade.

3. Determine the level of use of ECR and its possibilities in Baltic retail enterprises.

Research limits: 9 Baltic state experts in the retail trade were surveyed in order to identify the trends in the Baltic States and put forward the conditions for building and strengthening customer relationship management. The following limits were set due to the information necessary in the enterprise for ensuring customer relationship management: customer relationship management was researched primarily from the point of view of methodological aspects and the opinions of retail trade experts. Research period: 1st September 2014 to 1 st September 2016.

The following research methods were used: monograph or descriptive method, logical constructivist method - comparison of theoretical 
materials with empirical results; the experts' survey was processed using SPSS - to ascertain the level of use of ECR in retail enterprises in the Baltic States.

The methodological base of the research is based on works of foreign authors (Best R.; Doyle J.; Evans $M$. etc.) and publications in periodicals that provide an overview of trends in the field of customer relationship management and the novelties in the field.

\section{RESULTS AND DISCUSSION}

Many specialists, researchers and managers nowadays have come to the conclusion that under intense competitive circumstances one of the most significant success factors of enterprises is customer satisfaction with the range of products and services offered and their loyalty to products/brand/enterprise. In fact, a favourable attitude and loyalty are the basis for creating the enterprise's customer capital. However, to achieve the desired level of customer satisfaction and loyalty, the enterprise's relationships with its customers must be managed. Analysing the process of formation of satisfaction and loyalty the following correlations can be observed (refer figure 1).

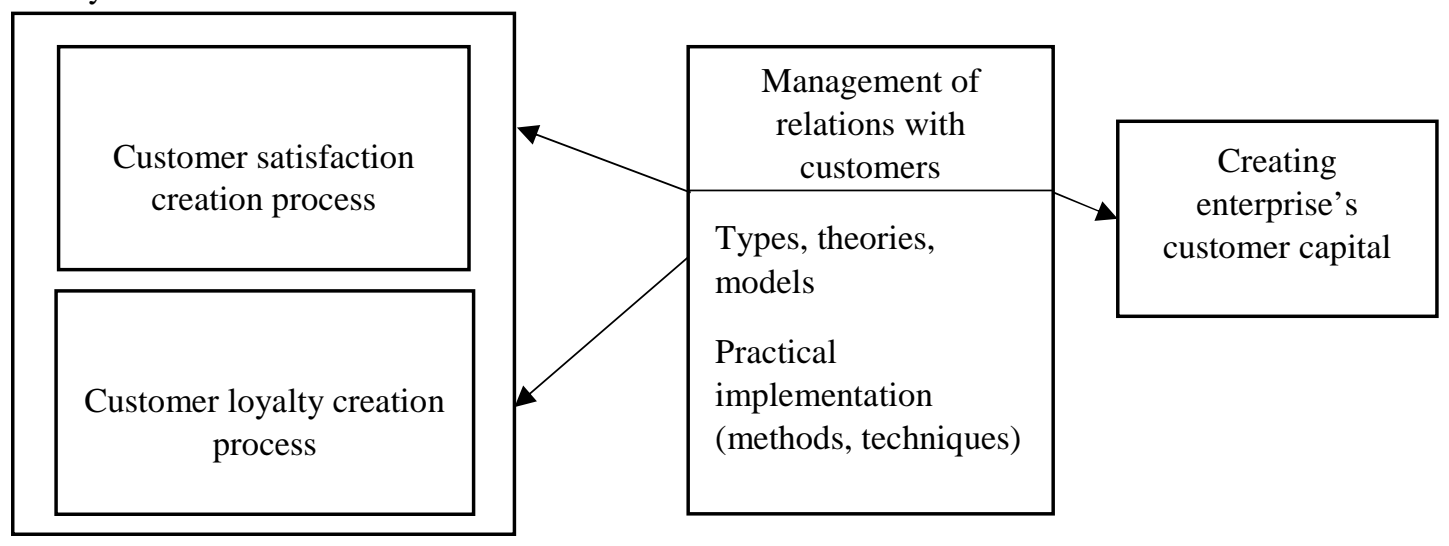

Fig. 1. Managing relationship with customers in connection with customer satisfaction and loyalty creation processes

Analysing several publications and other sources in the field of management of customer relationships $[15 ; 9 ; 3 ; 12 ; 20 ; 10 ; 2$ u's.], the authors have concluded that four systems researched in theory and applied in practice need to be highlighted:

1) Loyalty Programme - LP;

2) Consumer Relationship Management - CRM;
3) Efficient Consumer Response - ECR;

4) Relationship Marketing Management - RMM.

Retail enterprises use several management systems in practice but with evolution, each newly developed system includes both positive and tested elements of previous systems and new elements. This process is illustrated in figure 2 .

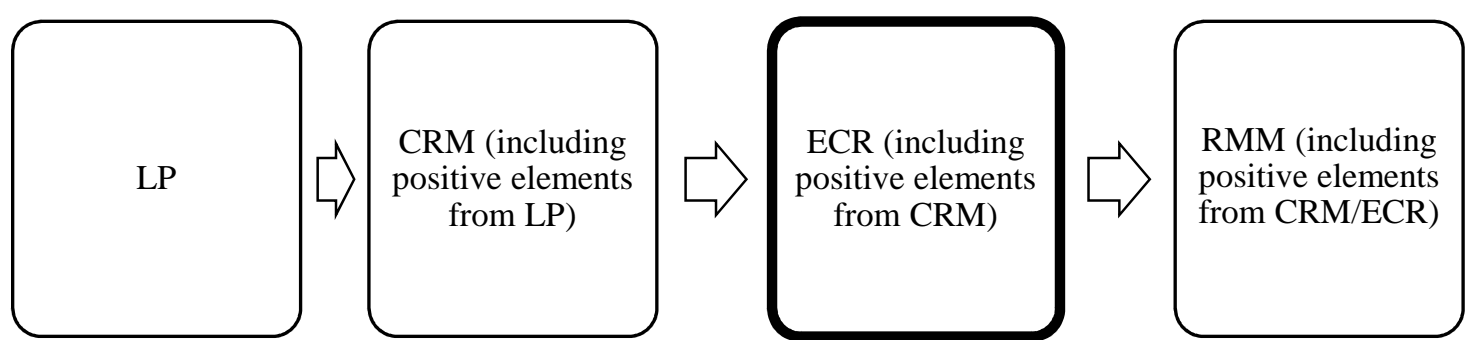

Fig. 2. Evolution of customer relationship management systems in retail trade

LP is used by many enterprises worldwide.

Characterising the advantages and drawbacks of LP one should distinguish its objectively inherent content and subjective implementation that do not always correspond to the demands. For example, both descriptions of positive as well as negative experiences can be found in scientific publications on this field $[12 ; 20 ; 3 ; 10$ etc.]. In this case the focus is on the subjective implementation of LP options, however the authors also point out some of its objective drawbacks:

- LP content, structure and types in fact relate only to the purchase/ sales process of products/brands even though the customer satisfaction/loyalty creation process which is the basis of customer relationship management is related to pre purchase and post purchase processes as well (refer figures 1.); 
- LP in fact does not impact the basic factors of customer satisfaction and loyalty (refer figures 1.);

- LP does not correspond to the dynamics of the customer satisfaction and loyalty creation process;

- Relatively less attention is paid to marketing research - modelling consumer behaviour, market segmentation etc.

These drawbacks to some extent may be overcome by using CRM, which on the one hand includes the positive elements from LP (customer segmentation, differentiation, stimulation, communication with them etc.), but on the other hand is the next stage in the field of creating and managing customer relationships.

Consumer relationship management (CRM) systems were followed by ECR (Efficient Consumer Response) which means „efficient response to meet consumer needs". Analysis of results of publications in the field of ECR $[5 ; 17 ; 11 ; 16 ; 18$ etc.) allow us to conclude that despite the insignificant differences all the authors consider that ECR is ,cooperation between retailers/distributors and manufacturers with the aim of satisfying customer needs and promoting prevention of irrational costs in the supply chain from the manufacturer to the consumer".

ECR became popular in developed countries in the mid 90 's of the $20^{\text {th }}$ century and the grounds for its creation was the increasing competition in world markets, rapid information technology development, creation and development of international trade organisations, necessity for optimisation of the distribution channel and growing consumer need for high value and high quality products and service quality. Researchers have underlined that it is the mutual trust between all the partners involved in the product supply process which is a prerequisite for achieving positive ECR results [5]. ECR is long term relationship with the respective stakeholders in the product supply process that foresees the management and resolution of disputes in a timely manner in order to achieve an overall positive result [18].

While agreeing to the statements of the abovementioned researchers regarding ECR one should however consider that it is unreasonable to plan and implement this relationship management system with consumers in practice separately and independently from the introduction of CRM in retail trade. In essence ECR is modernised and updated CRM as it serves the same purpose - managing relationships with consumers to satisfy their needs for products and increase their loyalty level. It is clear that close cooperation between manufacturers and retailers is necessary in this field. Improvement in product quality may mean nothing if retail enterprises are unable to ensure high quality service to their customers (CRM system function) and their loyalty indicators would go down due to the above reason. Summarising the information gathered it could be concluded that the efficient use of CRM and ECR systems are the basis for creation of consumer relationship management systems in retail enterprises.

ECR is more emphasised by Italian researchers [4], who highlight four important ECR blocks that comprise cooperation between manufacturers and retailers in the respective fields (refer table 1).

Table 1

Keys elements and fields of cooperation with suppliers in ECR systems

\begin{tabular}{|c|c|c|c|}
\hline \multicolumn{4}{|c|}{ ECR } \\
\hline Demand management & Supply management & $\begin{array}{c}\text { Integrating demand and } \\
\text { supply }\end{array}$ & Use of information technology \\
\hline $\begin{array}{l}\text { Needs and demands } \\
\text { Value creation for customers } \\
\text { Optimisation of product } \\
\text { assortment } \\
\text { Communication optimisation } \\
\text { Launching new products on the } \\
\text { market }\end{array}$ & $\begin{array}{l}\text { Identifying supply strategies and } \\
\text { possibilities } \\
\text { Supply standards and indicators } \\
\text { Supply corresponding to } \\
\text { demand } \\
\text { Supply corresponding to } \\
\text { demand from the "price-quality" } \\
\text { perspective } \\
\text { Supply efficiency }\end{array}$ & $\begin{array}{l}\text { Planning and forecasting } \\
\text { manufacturer and retailer } \\
\text { cooperation } \\
\text { Measuring effectiveness of } \\
\text { cooperation }\end{array}$ & $\begin{array}{l}\text { Identification standards } \\
\text { Information technology and } \\
\text { communication standards } \\
\text { Harmonising and synchronising } \\
\text { databases }\end{array}$ \\
\hline
\end{tabular}

One could agree to the conclusions of the „ECR Baltic" research that in case of efficient use of the system the following four parties could benefit from it: society, consumers, retailers and manufacturers [7].

The main benefits for the society from ECR: quick response to consumer needs; preventing loss and reducing costs in the product supply chain; ensuring high quality customer service.

Benefits for the consumer:
Greater choice and more convenient purchase according to consumer needs; Ensuring product sufficiency; Ensuring product variety.

Benefits for retailers:

Greater consumer trust and satisfaction with the service quality; wider possibilities of market research; enhancing relationships with suppliers; increasing efficiency of the supply chain.

Benefits for manufacturers:

Increasing production efficiency; 
Coordinating market demand with retailers;

Ensuring product sufficiency;

Ensuring product/brand positioning in the market;

Long term trading relations.

ECR foresees the creation of product assortment through product category management. Product category management assess assortment not as separate product sets but divides them into categories based on consumer needs and psychological aspects of product purchase [11]. Each retail enterprise works out its own product categories based on consumer needs and therefore consumer research and segmentation is necessary to ascertain and understand the target audience for each category and the perception of specific retail outlet (location, ambience etc.).

ECR in essence is based on CRM principles but has been appended with methods of cooperation between enterprises of the manufacturing and retail sector with the aim of ensuring satisfaction of consumer needs and reduction of supply chain costs. ECR also comprises such customer service approach as product category management which is rapidly developing in European countries.

Since regaining independence, retail trade in Latvia in particular and the Baltic States in general has developed with changing effects. For many years the sector has been one of the largest contributors to GDP. During the global economic crisis, retail was one of the economic sectors to experience the largest downturn. Since 2011, retail has developed similar to the economy as a whole. While retail is generally influenced by internal events, it is also indirectly affected by external factors. The Russian-Ukrainian conflict and the related sanctions, as well as the weak growth within the European Union (EU) leave negative impact on consumer behaviour and stimulate savings, thus hindering the total consumption.

To gain understanding on the situation in the Baltic State retail sector, the shadow economy index (SEI), which provides the best description of the industry situation was analysed (refer Figure 3).

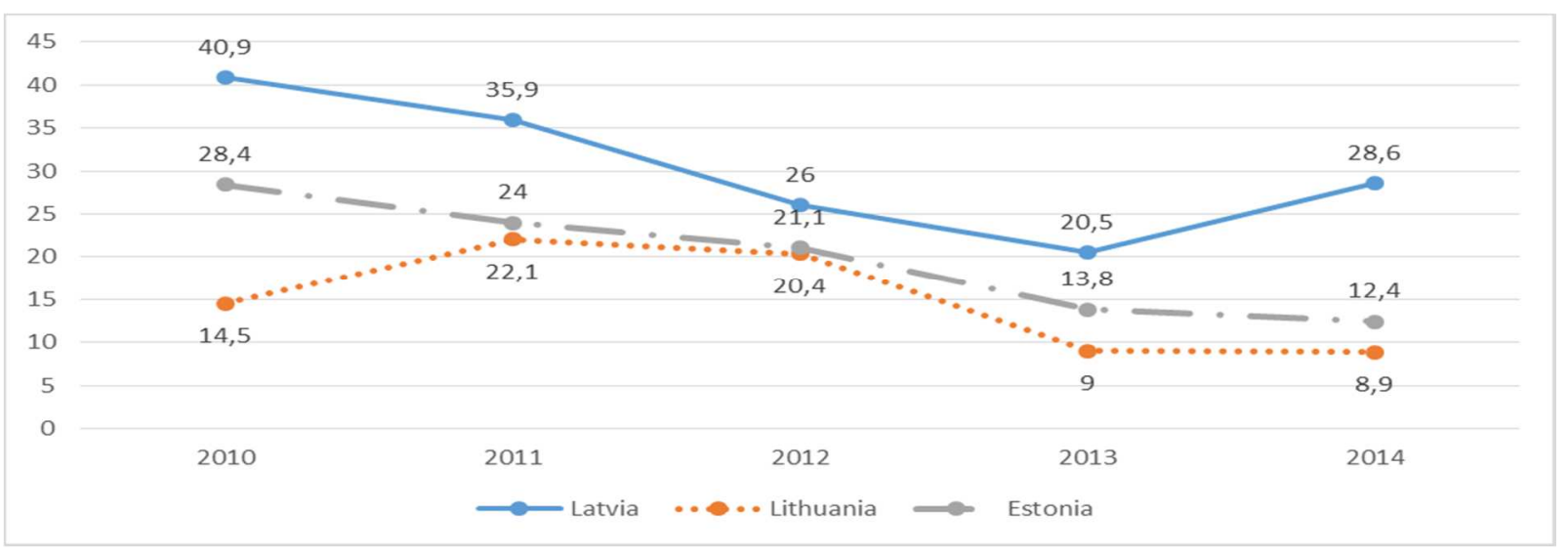

Fig. 3. Shadow economy in the Baltic State retail sector 2010 - 2014 (\% of GDP) (According to the data by Putnins, Sauka) [14]

As seen in Figure 3, Latvia is the leader among the Baltic States regarding shadow economy in the retail sector. While there was a positive trend from 2010 to 2013 with SEI decreasing by 20.4 percentage points, the indicator increased by 8.1 percentage points in 2014. It should be noted that the index was only $12.4 \%$ in Estonian retail sector in 2014. As well, for Estonia and Lithuania the index shows constant decrease trend. This means that companies can reach their goals applying legal and transparent business methods, incl. in the field of consumer relationship management.

For the evaluation of how entrepreneurs use consumer relationship management principles in retail enterprises in the Baltic States, it is vital to understand the current level and future prospects of CRM application. For this purpose, an expert survey was carried out. Taking into account the experts' knowledge level and connection to the relevant questions, 9 experts were selected -leading specialists of trade associations of the Baltic States, who evaluated the situation in their country in general, as well as the representatives of retail chains located in all three Baltic States, who evaluated the situation in their respective companies. 
Table 2

The use of ECR, incl. product category management in retail enterprises or enterprises on the whole in the Baltic States, key indicators for expert assessment

\begin{tabular}{|c|c|c|c|c|c|c|c|c|c|}
\hline 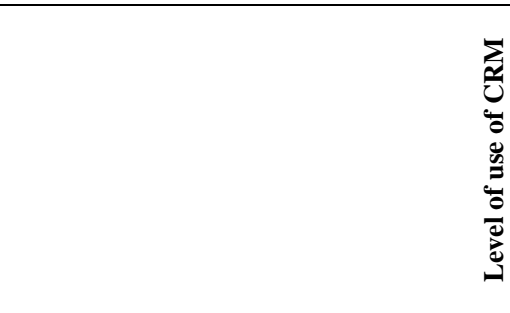 & $\sum_{\Sigma}^{\mathbb{E}}$ & 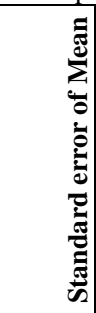 & 茎 & $\stackrel{\frac{g}{0}}{\underline{g}}$ & 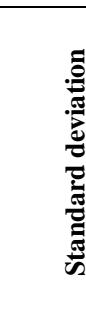 & 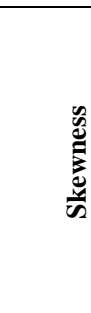 & 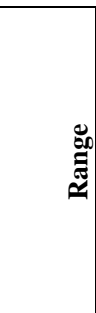 & 罵 & \\
\hline $\begin{array}{l}\text { Level of cooperation of product category } \\
\text { managers with suppliers of the same } \\
\text { category products }\end{array}$ & 5.33 & 0.78 & 5.00 & 4.00 & 2.35 & 5,5 & 4.89 & 9.00 & 48.00 \\
\hline $\begin{array}{l}\text { Product category managers use } \\
\text { information from CRM databases }\end{array}$ & 3.22 & 0.70 & 3.00 & 2.00 & 2.11 & 4.44 & 7.27 & 8.00 & 29.00 \\
\hline $\begin{array}{l}\text { Product category managers are responsible } \\
\text { for sales of products in the category }\end{array}$ & 5.78 & 0.76 & 6.00 & 6.00 & 2.28 & 5.19 & 4.38 & 9.00 & 52.00 \\
\hline $\begin{array}{l}\text { Product category managers determine } \\
\text { pricing for products in the category }\end{array}$ & 5.00 & 0.85 & 4.00 & 9.00 & 2.55 & 6,5 & 5.67 & 9.00 & 45.00 \\
\hline $\begin{array}{l}\text { Product category managers are responsible } \\
\text { for promotion of products in the category }\end{array}$ & 4.78 & 0.88 & 4.00 & 4.00 & 2.64 & 6.94 & 6.13 & 9.00 & 43.00 \\
\hline $\begin{array}{l}\text { Product category managers consult } \\
\text { salesmen of products in the category }\end{array}$ & 3.22 & 0.68 & 3.00 & 2.00 & 2.05 & 4.19 & 7.06 & 7.00 & 29.00 \\
\hline $\begin{array}{l}\text { Accessibility of product category managers } \\
\text { to information regarding customer } \\
\text { satisfaction }\end{array}$ & 4.67 & 0.82 & 5.00 & 8.00 & 2.45 & 6.00 & 5.83 & 8.00 & 42.00 \\
\hline $\begin{array}{l}\text { Possibilities of product category mangers } \\
\text { to respond to changes in consumer needs }\end{array}$ & 4.56 & 0.82 & 4.00 & 4.00 & 2.46 & 6.03 & 5.99 & 8.00 & 41.00 \\
\hline
\end{tabular}

As can be seen the use of ECR databases by product category managers is rather poor $(3.22-$ mean regarding use of ECR databases, incl. 5.33 for cooperation with suppliers; 4.67 - regarding customer satisfaction). Product category management is at a high level in some individual enterprises. Mo $=8$ and Mo $=9$ indicate the use of information regarding prices and customer satisfaction from ECR databases by product category managers. Approximately similar assessment, that is an insufficient level, (refer figure 2) indicates that the product category management should be enhanced as a whole and not just its separate elements. Moreover, the process should definitely be integrated with the ECR database. Otherwise, product category management will not be closely linked to the specific characteristics of the target audience, communication modes and consumer needs.

\section{CONCLUSIONS}

1. The retail trade sector in the Baltic States has developed at the same pace as the economy on the whole since the regaining of independence. Reviewing the situation according to the shadow economy index (SEI) Latvia is the leader among Baltic States in the retail trade sector $(28.5 \%$ in
2014). The SEI is only $12.4 \%$ for Estonia in 2014 and $8.9 \%$ for Lithuania. Moreover, the SEI index is constantly decreasing for Estonia and Lithuania. This means that companies can reach their goals through legal and transparent business methods, incl. in the field of management of consumer relationships.

2. Consumer relationship management systems are constantly evolving in retail trade both in theory and in practice (refer figure 2.). At present there is the development of CRM and ECR systems in retail trade. CRM is a company's operational strategy to attract, differentiate, serve and maintain consumers by understanding their needs and satisfying them, developing long term cooperation based on creating and maintaining consumer databases. ECR system elements and fields are being integrated into CRM systems.

3. The experts' survey indicates that the level of use of ECR in retail enterprises in the Baltic States is insufficient from the consumer needs satisfaction and loyalty creation perspective and therefore the systems need to be improved and developed taking into account the specifics of the target audience. 
4. In relation to the development of CRM/ECR systems in retail enterprises it is necessary to invest into and develop the product category management approach using CRM/ECR databases and coordinating it with other marketing and promotional activities.

5. In depth research has not been carried out in Latvia as yet on the benefits of ECR and its use that would convince retail enterprises to use it in a full-fledged manner.

6. Retail enterprises should use assortment management by category in their operations to ensure consumer satisfaction and loyalty as well as high quality service.

\section{REFERENCES}

[1] Anderson, J. L., Jolly, L. D., Fairhurst, A. E. (2007). Customer relationship management in retailing: a content analysis of retail trade journals. Journal of Retailing and Consumers services, November, 14(6).

[2] Best, R. (2005). Market based management. $4^{\text {th }}$ ed., Prentice Hall.

[3] Butcher, S., Stephan, A. (2002). Customer Clubs on Loyalty Programmes. Abingdon, Oxsn, GBR: Gower Publishing Limited.

[4] Butsonera, A., Martini, P., Zavattini, G., Santona, A. (2014). Psychometric properties of an Italian version of the experiences in chose relationships - revised (ECR-R) scale. Psychological Reports, ISSN: 0033-2941, Jun, vol. 114 issue 3, pp. 785-81.

[5] Dyer, J. H., Harbir, S. (1998). The Relational View: Cooperative Strategy and Sources of interorganizational Competitive Advantage. Academy of management Review, 23 (4), pp. 660-679.
[6] Doyle, P., Stern, P. (2006). Marketing management and strategy, $4^{\text {th }}$ ed. Prentice Hall, pp. 401-432.

[7] ECR Baltic (b.g.). Retrieved 08.08.2015 from http://www.ecr-baltic.org/en/about-ecr/efektiva-pateretajuvajadzibu-novertesana-ecr/

[8] ECR Europe (b.g.). Retrieved 05.07.2016 from http://www.ecrnet.org/01-about/01-about1-2.html.

[9] Evans, M. (2012). Consumer Behaviour. Hoboken, NJ, Willy.

[10] Harker, M. J. (1999). Relationship Marketing defined. MCB University Press, Bradford, pp. 13-20.

[11] Hofstetter, J. (2006). Accessing the contribution to ECR. ECR journal, vol. 6 issue 1, pp. 20-29.

[12] Kotler, P., Keller, K. L. (2006). Marketing management. $12^{\text {th }}$ ed., Prentice Hall, pp. 196-197.

[13] Kurt Salmon Associates (1993), Efficient Consumer Response - Enhancing Consumer Value in the Grocery Industry. Washington, DC: Food Marketing Institute.

[14] Putninšs, T.J. \& Sauka A., (2015). Ēnu ekonomikas indekss Baltijas valstīs 2009 - 2014. Rīga: SSE Riga Ilgtspējīga biznesa centrs, 47 lpp.

[15] Reisheld, F. (2003). The One Number You Need to grow. Harvard Business Review, December.

[16] Salmon, K. (1993). Efficient Consumer ResponseEnhancing Consumer Value in the Grocery industry. Washington DC, Food Marketing Institute.

[17] Seifert, D. (2001). Efficient Consumer Response. Hampp, Mering.

[18] Smith, P. R., Zook, Z. (2011). Marketing Communication. $5^{\text {th }}$ ed. Kogan Page, PA, pp.

[19] Teece, D. J., Gary, P., Amy, S. (1997). Dynamic Capabilities and Strategic Management. Strategic Management Journal, 18(7), pp. 509-533.

[20] Toedt, M. (2015). The contribution of customer relationship management to sales performance in the hotel business. Summary of Doctoral Thesis, University of Latvia, Riga. 